\title{
Sphingopyxis ginsengisoli sp. nov., isolated from soil of a ginseng field in South Korea
}

\author{
Correspondence \\ Wan-Taek Im \\ wandra@kaist.ac.kr \\ Sung-Taik Lee \\ e_stlee@kaist.ac.kr
}

\author{
Myungjin Lee, ${ }^{1}$ Leonid N. Ten, ${ }^{2}$ Hae-Won Lee, ${ }^{1}$ Hyun Woo Oh, ${ }^{3}$ \\ Wan-Taek $\mathrm{Im}^{1}$ and Sung-Taik Lee ${ }^{1}$
}
${ }^{1}$ Department of Biological Sciences, Korea Advanced Institute of Science and Technology, 373-1, Guseong-dong, Yuseong-gu, Daejeon 305-701, Republic of Korea
${ }^{2}$ Department of Biology and Medicinal Science, Pai Chai University, 14 Yeonja-1-Gil, Seo-Gu, Daejeon 302-735, Republic of Korea
${ }^{3}$ Insect Resources Research Center, Korea Research Institute of Bioscience and Biotechnology (KRIBB), 52 Oeundong, Yusong-gu, Daejeon 305-333, Republic of Korea

A major cultivation area of ginseng plant (Panax ginseng C.A. Meyer) in South Korea includes Pocheon, Kanghwa, Geumsan, Chonkok, Kimpo, Yongin, Anseong and Suhsan. During the course of a study on the culturable aerobic bacterial community in soil from a ginseng field in Pocheon province, a large number of novel bacterial strains were isolated (Im et al., 2005). One of these isolates (strain Gsoil $250^{\mathrm{T}}$ ) appeared to be a member of the genus

The GenBank/EMBL/DDBJ accession number for the 16S rRNA gene sequence of strain Gsoil $250^{\top}$ is AB245343.

Figures showing a transmission electron micrograph of a negatively stained single cell of strain Gsoil $250^{\top}$ and a two-dimensional, thin-layer chromatograph of the polar lipids and a table detailing the cellular fatty acid profiles of strain Gsoil $250^{\top}$ and related species of the genus Sphingopyxis are available as supplementary material with the online version of this paper.
Sphingopyxis in the Alphaproteobacteria lineage and was subjected to a taxonomic investigation.

The genus Sphingopyxis was first described by Takeuchi et al. (2001) and at present the genus comprises eight species: Sphingopyxis macrogoltabida (Takeuchi et al., 1993, 2001), Sphingopyxis terrae (Takeuchi et al., 1993, 2001), Sphingopyxis witflariensis (Kämpfer et al., 2002), Sphingopyxis alaskensis (Vancanneyt et al., 2001; Godoy et al., 2003), Sphingopyxis chilensis (Godoy et al., 2003), Sphingopyxis flavimaris (Yoon \& Oh, 2005), Sphingopyxis baekryungensis (Yoon et al., 2005) and Sphingopyxis taejonensis ( $\mathrm{Pal}$ et al., 2006).

In the present study, we conducted a phylogenetic analysis based on 16S rRNA gene sequences, DNA-DNA hybridization and an analysis of the phenotypic, genotypic and chemotaxonomical characteristics to determine the precise taxonomic position of strain Gsoil $250^{\mathrm{T}}$. On the basis of the results obtained in this study, we propose that strain Gsoil 
$250^{\mathrm{T}}$ should be placed in the genus Sphingopyxis as the type strain of novel species.

Strain Gsoil $250^{\mathrm{T}}$ was isolated originally from a soil sample from a ginseng field in Pocheon province (South Korea) by using modified R2A medium, as described previously (Ten et al., 2006). Single colonies on the plates were purified by transferring them onto fresh plates of modified R2A or half-strength modified R2A agar and incubating again. Purified colonies were tentatively identified from partial sequences of the 16S rRNA gene (Im et al., 2005). Strain Gsoil $250^{\mathrm{T}}$ was one of the isolates that appeared on the modified R2A agar plates under aerobic conditions. The strain was cultured routinely on R2A agar (Difco) at $30{ }^{\circ} \mathrm{C}$ and maintained as a glycerol suspension $(20 \%$, w/v) at $-70{ }^{\circ} \mathrm{C}$.

The Gram reaction was performed by using the nonstaining method as described by Buck (1982). Cell morphology was observed using a Nikon light microscope at $\times 1000$, with cells grown for 3 days at $30{ }^{\circ} \mathrm{C}$ on $\mathrm{R} 2 \mathrm{~A}$ agar. Catalase activity was determined by bubble production in $3 \%(\mathrm{v} / \mathrm{v}) \mathrm{H}_{2} \mathrm{O}_{2}$ and oxidase activity was determined using $1 \% \quad(\mathrm{w} / \mathrm{v})$ tetramethyl p-phenylenediamine. Anaerobic growth, nitrate reduction and assimilation of single carbon sources were determined at $30{ }^{\circ} \mathrm{C}$ as reported previously (Ten et al., 2006). Some physiological characteristics were determined using API 20E galleries according to the instructions of the manufacturer (bioMérieux). Tests for degradation of DNA [in which DNase agar (Scharlau) plates were flooded with $1 \mathrm{M} \mathrm{HCl}$ ), casein, chitin, starch (Atlas, 1993), lipid (Kouker \& Jaeger, 1987), xylan and cellulose (Ten et al., 2004) were performed and evaluated after 5 days. Growth at different temperatures $\left(4,15,25,30,37\right.$ and $\left.42{ }^{\circ} \mathrm{C}\right)$ and various $\mathrm{pH}$ values ( $\mathrm{pH} 5.0-10.0$, in increments of $0.5 \mathrm{pH}$ units) was assessed after 5 days incubation. Salt tolerance was tested on R2A medium supplemented with $1-10 \%(w / v) ~ N a C l$ after 5 days incubation. Growth on nutrient agar, trypticase soy agar (TSA; Difco) and MacConkey agar was also evaluated at $30{ }^{\circ} \mathrm{C}$.

Extraction of the genomic DNA was achieved using a commercial genomic DNA extraction kit (Core Biosystem), and PCR-mediated amplification of the $16 \mathrm{~S}$ rRNA gene and sequencing of the purified PCR product were carried out according to Kim et al. (2005). The full sequence of the 16S rRNA gene was compiled using SeqMan software (DNASTAR). The 16S rRNA gene sequences of related taxa were obtained from the GenBank database. Multiple alignments were performed by using the program CLUSTAL_X (Thompson et al., 1997). Gaps were edited in the program BioEdit (Hall, 1999). The evolutionary distances were calculated using the Kimura two-parameter model (Kimura, 1983). Phylogenetic trees were constructed using the neighbour-joining (Saitou \& Nei, 1987) and maximum-parsimony (Fitch, 1971) methods in the program MEGA3 (Kumar et al., 2004), with bootstrap values based on 1000 replications (Felsenstein, 1985).
To measure the $\mathrm{G}+\mathrm{C}$ content of the chromosomal DNA, the genomic DNA of the strains was extracted and purified as described by Moore \& Dowhan (1995) and enzymically degraded into nucleosides. The DNA G $+\mathrm{C}$ content was then determined as described by Mesbah et al. (1989) using reversed-phase HPLC. Isoprenoid quinones were extracted with chloroform/methanol $(2: 1, \mathrm{v} / \mathrm{v})$, evaporated under vacuum conditions, and re-extracted in $n$-hexane-water $(1: 1, \mathrm{v} / \mathrm{v})$. The crude quinone in $n$-hexane was purified using Sep-Pak Vac cartridges (Waters) and was subsequently analysed by HPLC, as described previously (Hiraishi et al., 1996). Cellular fatty acids were analysed in organisms grown on TSA for 2 days. The cellular fatty acids were saponified, methylated and extracted according to the protocol of the Sherlock Microbial Identification System (MIDI). The fatty acids were then analysed by gas chromatography (model 6890; Hewlett Packard) using the Microbial Identification software package (Sasser, 1990). Polar lipids were extracted using the procedures described by Minnikin et al. (1984) and identified by twodimensional TLC followed by spraying with appropriate detection reagents (Komagata \& Suzuki, 1987).

Cells of strain Gsoil $250^{\mathrm{T}}$ were Gram-negative, aerobic, motile and rod-shaped $(0.2-0.3 \mu \mathrm{m}$ in diameter and $1.0-$ $1.2 \mu \mathrm{m}$ in length), with single polar flagella (see Supplementary Fig. S1, available in IJSEM online). The strain could not grow anaerobically supplemented with nitrate. Colonies grown on R2A agar plates for 4 days were smooth, circular, non-glossy, yellowish in colour and 1$3 \mathrm{~mm}$ in diameter. On R2A agar, strain Gsoil $250^{\mathrm{T}}$ was able to grow at $4-42{ }^{\circ} \mathrm{C}$, but not at $45{ }^{\circ} \mathrm{C}$. Physiological characteristics of strain Gsoil $250^{\mathrm{T}}$ are summarized in the species description and selected characteristics that differentiate it from related Sphingopyxis species are listed in Table 1.

The 16S rRNA gene sequence of strain Gsoil $250^{\mathrm{T}}$ obtained was a continuous stretch of $1455 \mathrm{bp}$. Sequence similarity calculation after a neighbour-joining analysis indicated that the closest relatives of strain Gsoil $250^{\mathrm{T}}$ were S. macrogoltabida NBRC $15033^{\mathrm{T}}$ (98.7\%), S. chilensis LMG $20986^{\mathrm{T}}$ $(98.2 \%)$, S. alaskensis LMG $18877^{\mathrm{T}}(97.9 \%)$, S. taejonensis KCTC $2884^{\mathrm{T}}(97.9 \%)$ and S. witflariensis DSM $14551^{\mathrm{T}}$ $(97.8 \%)$. Lower sequence similarities $(<96.2 \%)$ were found with other established species of the genus Sphingopyxis. This relationship between strain Gsoil $250^{\mathrm{T}}$ and other members of the genus Sphingopyxis was also evident in the phylogenetic tree (Fig. 1). Strain Gsoil $250^{\mathrm{T}}$ and six closely related Sphingopyxis species (S. macrogoltabida, S. chilensis, S. alaskensis, S. taejonensis, S. witflariensis and S. terrae) formed a monophyletic clade with a high bootstrap value $(97 \%)$, which was supported by the two types of treemaking methods employed in this study.

DNA-DNA hybridization was performed between Gsoil $250^{\mathrm{T}}$ and the type strains of recognized species of the genus Sphingopyxis according to the method of Ezaki et al. (1989), using photobiotin-labelled DNA probes (Sigma) 
Table 1. Differential phenotypic characteristics of strain Gsoil $250^{\top}$ (Sphingopyxis ginsengisoli sp. nov.) and recognized Sphingopyxis species

Species: 1, Gsoil 250 (data from this study); 2, S. macrogoltabida ( $n=6$ ) (Takeuchi et al., 1993, 1995; Kämpfer et al., 1997; Lee et al., 2001); 3, S. alaskensis ( $n=7$ ) (Vancanneyt et al., 2001); 4, S chilensis ( $n=1$ ) (Godoy et al., 2003); 5, S. taejonensis ( $n=1$ ) (Lee et al., 2001); 6, S. witflariensis ( $n=1$ ) (Kämpfer et al., 2002); 7, S. terrae ( $n=6$ ) (Takeuchi et al., 1993, 1995; Kämpfer et al., 1997; Lee et al., 2001); 8, S. baekryungensis ( $n=1$ ) (Yoon \& Oh, 2005); 9, S. flavimaris (Yoon et al., 2005) ( $n=1$ ). All species are Gram-negative, rod-shaped, non-spore-forming, motile and catalase- and oxidase-positive. All species are negative for utilization of citrate. $n$, Number of strains; +, positive; - , negative; $\mathrm{W}$, weakly positive; ND, not determined; $\mathrm{v}$, variable reaction. Data in parentheses are for the type strain.

\begin{tabular}{|c|c|c|c|c|c|c|c|c|c|}
\hline Characteristic & 1 & 2 & 3 & 4 & 5 & 6 & 7 & 8 & 9 \\
\hline Colony colour & Yellow & $\begin{array}{c}\text { Whitish-brown or } \\
\text { yellow }\end{array}$ & Yellow to beige & Yellow & Pale-yellow & Yellow & $\begin{array}{c}\text { Light or deep- } \\
\text { yellow }\end{array}$ & Orange & Yellow \\
\hline Motility & + & + & + & + & + & + & $\mathrm{v}(+)$ & + & + \\
\hline $\begin{array}{l}\text { Reduction of nitrate } \\
\text { to nitrite }\end{array}$ & - & - & - & - & - & - & - & + & - \\
\hline \multicolumn{10}{|l|}{ Hydrolysis of: } \\
\hline Aesculin & + & $\mathrm{v}(+)$ & + & + & - & - & $\mathrm{v}(-)$ & + & - \\
\hline Gelatin & - & $\mathrm{V}(-)$ & - & - & - & - & - & - & - \\
\hline Urea & - & - & $\mathrm{V}(+)$ & - & - & - & - & - & - \\
\hline \multicolumn{10}{|l|}{ Utilization of: } \\
\hline Acetate & + & $(+)$ & - & $-*$ & $-*$ & - & $(-)$ & + & - \\
\hline L-Arabinose & - & + & - & - & - & - & - & + & - \\
\hline Cellobiose & + & + & $\mathrm{V}(-)$ & $+^{*}$ & $+^{*}$ & - & + & + & + \\
\hline Fructose & - & - & - & + & $-*$ & - & - & - & - \\
\hline D-Galactose & + & $(-)$ & $\mathrm{v}(+)$ & $+^{*}$ & $-{ }^{\star}$ & - & $(-)$ & - & - \\
\hline D-Glucose & + & $(+)$ & + & + & $+^{*}$ & + & $(-)$ & + & + \\
\hline Malate & + & - & + & + & + & - & + & $\mathrm{W}$ & - \\
\hline Maltose & + & + & + & + & - & + & + & - & - \\
\hline Mannose & - & - & - & + & - & - & - & + & - \\
\hline Trehalose & - & + & + & $+^{*}$ & $-*$ & - & + & - & - \\
\hline Xylose & - & - & - & $\mathrm{w}$ & $-{ }^{*}$ & - & - & - & + \\
\hline \multicolumn{10}{|l|}{$\begin{array}{l}\text { Nucleotide signature } \\
\text { of } 16 \mathrm{~S} \text { rRNA gene: }\end{array}$} \\
\hline $134 \dagger$ & G & G & G & G & G & G & G & G & A \\
\hline $990: 1215^{\star}$ & $\mathrm{U}: \mathrm{G}$ & $\mathrm{U}: \mathrm{G}$ & $\mathrm{U}: \mathrm{G}$ & $\mathrm{U}: \mathrm{G}$ & $\mathrm{U}: \mathrm{G}$ & $\mathrm{U}: \mathrm{A}$ & $\mathrm{U}: \mathrm{G}$ & $\mathrm{U}: \mathrm{A}$ & $\mathrm{U}: \mathrm{A}$ \\
\hline Major fatty acids & $\begin{array}{c}\mathrm{C}_{18: 1} \omega 7 c \\
\mathrm{C}_{16: 1} \omega 7 c / \text { iso- } \mathrm{C}_{15: 0} \\
2-\mathrm{OH}, \mathrm{C}_{16: 0}\end{array}$ & $\begin{array}{c}\mathrm{C}_{18: 1} \omega 7 c \\
\mathrm{C}_{16: 1} \omega 7 c / \text { iso- } \mathrm{C}_{15: 0} \\
2-\mathrm{OH}, \mathrm{C}_{17: 1} \omega 6 c\end{array}$ & $\begin{array}{c}\mathrm{C}_{17: 1} \omega 6 c \\
\mathrm{C}_{18: 1} \omega 7 c\end{array}$ & $\begin{array}{c}\mathrm{C}_{18: 1} \omega 7 c \\
\mathrm{C}_{17: 1} \omega 6 c\end{array}$ & $\begin{array}{c}\mathrm{C}_{18: 1} \omega 7 c / \mathrm{C}_{18: 1} \omega 9 t / \\
\mathrm{C}_{18: 1} \omega 12 t \\
\mathrm{C}_{16: 0}\end{array}$ & $\begin{array}{c}\mathrm{C}_{17: 1} \omega 6 c \\
\mathrm{C}_{16: 1} \omega 7 c / \text { iso- } \mathrm{C}_{15: 0} \\
2-\mathrm{OH}\end{array}$ & $\begin{array}{c}\mathrm{C}_{17: 1} \omega 6 c \\
\mathrm{C}_{18: 1} \omega 7 c\end{array}$ & $\begin{array}{c}\mathrm{C}_{18: 1} \omega 7 c \\
\mathrm{C}_{17: 1} \omega 6 c\end{array}$ & $\begin{array}{c}\mathrm{C}_{18: 1} \omega 7 c, \\
\mathrm{C}_{16: 1} \omega 7 c / \text { iso- } \\
\mathrm{C}_{15: 0} 2-\mathrm{OH}, \\
\mathrm{C}_{17: 1} \omega 6 c\end{array}$ \\
\hline $\begin{array}{l}\text { DNA G }+\mathrm{C} \text { content } \\
(\mathrm{mol} \%)\end{array}$ & 69.2 & $63-65$ & 65 & 66 & 63 & ND & $63-65$ & 63 & 58 \\
\hline
\end{tabular}

${ }^{\star}$ Data from this study.

$\dagger$ Escherichia coli 16S rRNA numbering system was used. 


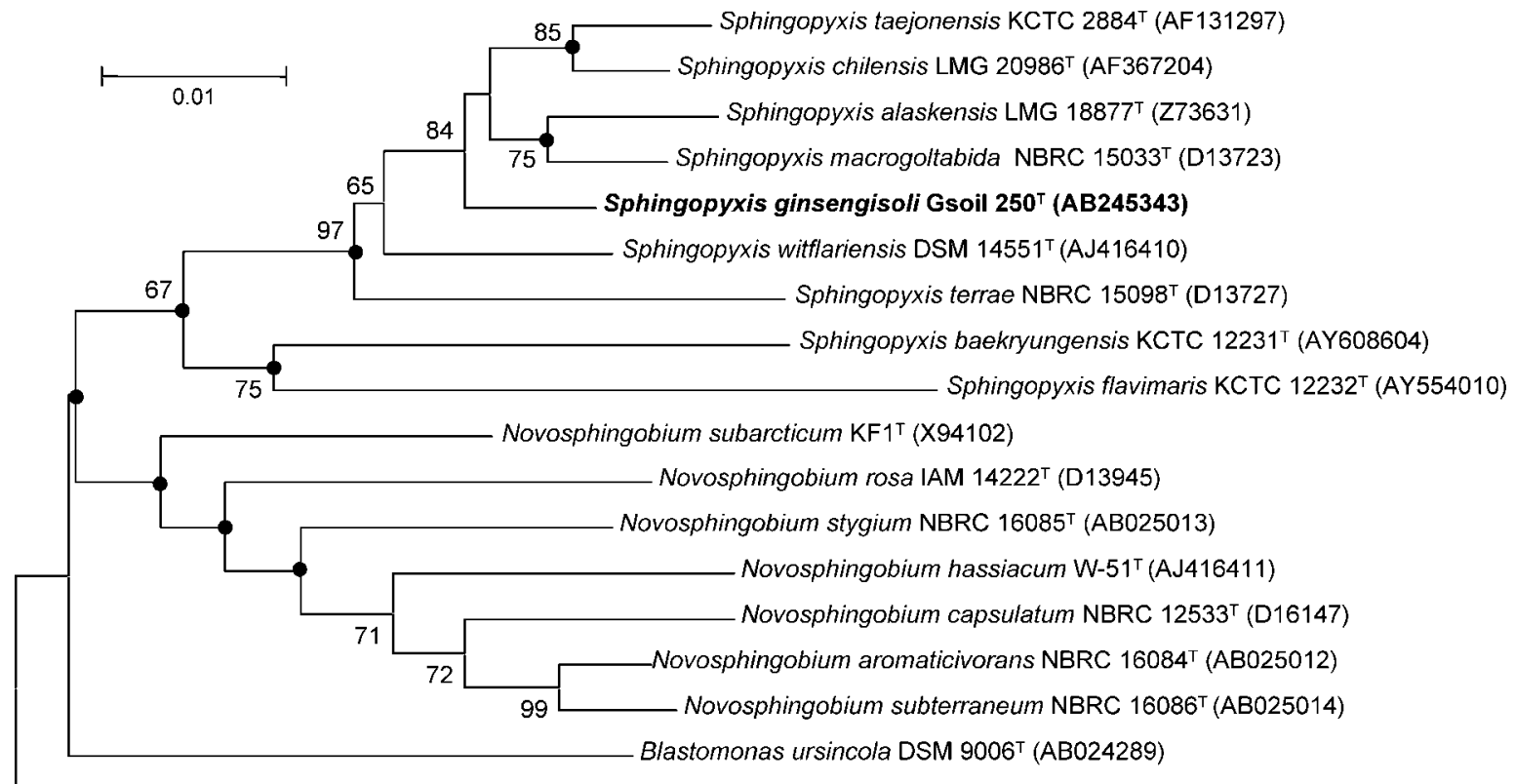

Sphingomonas paucimobilis GIFU $2395^{\top}$ (D16144)

Fig. 1. Phylogenetic tree constructed from a comparative analysis of $16 \mathrm{~S}$ rRNA gene sequences showing the relationship of strain Gsoil $250^{\top}$ (Sphingopyxis ginsengisoli sp. nov.) with other related species. Bootstrap values (expressed as a percentage of 1000 replications) $\geqslant 65 \%$ are shown at branch points. Solid circles indicate that the corresponding nodes were also recovered in the tree generated with the maximum-parsimony algorithm. Bar, 0.01 substitutions per nucleotide position.

and microdilution wells (Greiner). The levels of DNA-DNA relatedness between strain Gsoil $250^{\mathrm{T}}$ and recognized species of the genus Sphingopyxis were 9-29\% (15\% to S. macrogoltabida NBRC $15033^{\mathrm{T}}, 29 \%$ to S. chilensis LMG $20986^{\mathrm{T}}, 10 \%$ to $S$. alaskensis $\mathrm{LMG} 18877^{\mathrm{T}}, 13 \%$ to $S$. taejonensis KCTC $2884^{\mathrm{T}}$ and $12 \%$ to S. witflariensis DSM $14551^{\mathrm{T}}$, values that are low enough to assign strain Gsoil $250^{\mathrm{T}}$ as representing a novel species of the genus Sphingopyxis (Wayne et al., 1987; Stackebrandt \& Goebel, 1994).

The DNA G+C content of strain Gsoil $250^{\mathrm{T}}$ was $69.2 \mathrm{~mol} \%$. The predominant respiratory lipoquinone type (Q-10) of strain Gsoil $250^{\mathrm{T}}$ was the same as those of recognized species of the genus Sphingopyxis (Takeuchi et al., 2001; Kämpfer et al., 2002; Yoon et al., 2005). The fatty acid profile of strain Gsoil $250^{\mathrm{T}}$ was characterized by the occurrence of $\mathrm{C}_{18: 1} \omega 7 c(46.4 \%)$, summed feature 4 $\left(\mathrm{C}_{16: 1} \omega 7 c /\right.$ iso- $\left.\mathrm{C}_{15: 0} 2-\mathrm{OH} ; 34.6 \%\right)$ and $\mathrm{C}_{16: 0}(9.7 \%)$ as major fatty acids, and $\mathrm{C}_{14: 0} 2-\mathrm{OH}(5.1 \%)$ as a 2-hydroxy fatty acid and the absence of 3-hydroxy fatty acids. This cellular fatty acid profile was similar to that of the phylogenetically closest relative $S$. macrogoltabida NBRC $15033^{T}$ and those of some other members of the genus Sphingopyxis (see Supplementary Table S1, available in IJSEM online). The lack of 3-hydroxy fatty acids and the presence of 2-hydroxy myristic acid are characteristics that are also shared by all recognized species of the genus Sphingopyxis (Takeuchi et al., 2001; Kämpfer et al., 2002; Godoy et al., 2003; Yoon \& Oh, 2005; Yoon et al., 2005). However, some qualitative and quantitative differences in fatty acid content could be observed between strain Gsoil $250^{\mathrm{T}}$ and its phylogenetically close relatives. In particular, strain Gsoil $250^{\mathrm{T}}$ could be differentiated from some other Sphingopyxis species by a higher content of $\mathrm{C}_{18: 1} \omega 7 \mathrm{c}$, the absence of $\mathrm{C}_{18: 0}$ and by a smaller amount of $\mathrm{C}_{17: 1} \omega 6 \mathrm{c}$. Significant quantitative variation of the latter fatty acid was reported previously by Kämpfer et al. (2002) and was also observed between different species of the genus Sphingomonas (Kämpfer et al., 1997; Asker et al., 2007).

Two-dimensional TLC analysis of polar lipids extracted from strain Gsoil $250^{\mathrm{T}}$ (see Supplementary Fig. S2, available in IJSEM Online) showed that strain Gsoil $250^{\mathrm{T}}$ contained a sphingoglycolipid, clearly suggesting that the bacterium belongs to subgroup 4 of the Alphaproteobacteria. The overall polar lipid pattern of strain Gsoil $250^{\mathrm{T}}$ corresponded to those reported for sphingomonads (Busse et al., 1999), in particular, for the genus Sphingopyxis (Kämpfer et al., 2002; Yoon \& Oh, 2005; Yoon et al., 2005), as it was composed of phosphatidylglycerol, phosphatidylcholine, phosphatidylethanolamine, diphosphatidylglycerol and sphingoglycolipid. Small amounts of phosphatidylmonomethylethanolamine, which has been detected in the majority of members of the genus Sphingopyxis, were also present in strain Gsoil $250^{\mathrm{T}}$. However, Gsoil $250^{\mathrm{T}}$ has several significant differences in polar lipid composition from that of its closest relative, S. macrogoltabida NBRC $15033^{\mathrm{T}}$ (Busse et al., 1999). In contrast to S. macrogoltabida, strain Gsoil $250^{\mathrm{T}}$ produced large amounts of two unknown glycolipids, GL2 and GL3, minor amounts of aminolipid AL and unknown lipids L1 
and L2. The unique combination of six unknown polar lipids as well as the proportion of common polar lipids was very useful for differentiation of strain Gsoil $250^{\mathrm{T}}$ from other species of the genus Sphingopyxis (Kämpfer et al., 2002; Yoon \& Oh, 2005; Yoon et al., 2005).

All of the characteristics determined for strain Gsoil $250^{\mathrm{T}}$ were in accordance with those of members of the genus Sphingopyxis. However, on the basis of phylogenetic distances from established Sphingopyxis species, low levels of DNA-DNA relatedness, and the combination of unique phenotypic characteristics (Table 1), it is clear that strain Gsoil $250^{\mathrm{T}}$ is not affiliated with any recognized species of the genus Sphingopyxis. Therefore, based on the data presented, strain Gsoil $250^{\mathrm{T}}$ should be placed in the genus Sphingopyxis as representing a novel species, for which the name Sphingopyxis ginsengisoli sp. nov. is proposed.

\section{Description of Sphingopyxis ginsengisoli sp. nov.}

Sphingopyxis ginsengisoli (gin.sen.gi.so'li. N.L. n. ginsengum ginseng; L. n. solum soil; N.L. gen. n. ginsengisoli of soil of a ginseng field, the source of the organism).

Cells are Gram-negative, aerobic, positive for catalase and oxidase, and rod-shaped $(0.2-0.3 \mu \mathrm{m}$ in diameter and $1.0-1.2 \mu \mathrm{m}$ in length after 4 days culture on R2A agar). Cells are motile by means of single polar flagella. Colonies grown on R2A agar plates for 4 days are smooth, circular, non-glossy, yellowish in colour and $1-3 \mathrm{~mm}$ in diameter. Growth occurs at $4-42{ }^{\circ} \mathrm{C}$ and $\mathrm{pH}$ 5.0-8.5. Growth occurs in the absence of $\mathrm{NaCl}$ and in the presence of $5.0 \%(\mathrm{w} / \mathrm{v})$ $\mathrm{NaCl}$. Does not grow anaerobically in R2A broth medium supplemented with nitrate. Xylan, chitin, starch, cellulose and DNA are not degraded. Growth occurs on TSA and nutrient agar, but not on MacConkey agar. Substrate utilization, enzyme production and other physiological characteristics are given in Table 1. In addition, the following substrates are utilized for growth: D-lyxose, Lxylose, D-fucose, L-rhamnose, propionate, 3-hydroxybutyrate, valerate, lactate, adipate, suberate, fumarate, succinate, amygdalin, L-alanine, L-asparagine, L-aspartic acid, Lglutamic acid, L-glutamine, L-histidine, L-isoleucine, Lleucine, L-proline and L-tryptophan. The following substrates are not utilized for growth: L-sorbose, D-arabinose, D-ribose, $\mathrm{N}$-acetylglucosamine, pyruvate, formate, caprate, maleic acid, phenylacetate, benzoate, 3-hydroxybenzoate, 4-hydroxybenzoate, salicin, citrate, malonate, glutarate, tartrate, itaconate, oxalate, D-lactose, melibiose, sucrose, raffinose, gluconate, D-adonitol, dulcitol, inositol, Dmannitol, D-sorbitol, xylitol, glycerol, methanol, ethanol, glycogen, inulin, dextran, L-arginine, L-lysine, L-methionine, L-phenylalanine, L-serine, L-threonine, L-tyrosine and L-valine. $\mathrm{H}_{2} \mathrm{~S}$ and indole are not produced. Arginine dihydrolase and tryptophan deaminase are produced, but not lysine decarboxylase, ornithine decarboxylase or urease. Predominant respiratory lipoquinone is Q-10. Major fatty acids are $\mathrm{C}_{18: 1} \omega 7 c(46.4 \%), \mathrm{C}_{16: 1} \omega 7 c /$ iso$\mathrm{C}_{15: 0} 2-\mathrm{OH}(34.6 \%) ; 2$-hydroxy fatty acid is also present.
Major polar lipids are sphingoglycolipid, phosphatidylglycerol, phosphatidylcholine, phosphatidylethanolamine, diphosphatidylglycerol and two unknown glycolipids. The DNA $\mathrm{G}+\mathrm{C}$ content of the type strain is $69.2 \mathrm{~mol} \%$.

The type strain, Gsoil $250^{\mathrm{T}}\left(=\mathrm{KCTC} 12582^{\mathrm{T}}=\mathrm{LMG}\right.$ $\left.23390^{\mathrm{T}}\right)$, was isolated from soil of a ginseng field in Pocheon province, South Korea.

\section{Acknowledgements}

This work was supported by the 21C Frontier Microbial Genomics and Applications Center Program, Ministry of Education, Science \& Technology, Republic of Korea.

\section{References}

Asker, D., Beppu, T. \& Ueda, K. (2007). Sphingomonas jaspsi sp. nov., a novel carotenoid-producing bacterium isolated from Misasa, Tottori, Japan. Int J Syst Evol Microbiol 57, 1435-1441.

Atlas, R. M. (1993). Handbook of Microbiological Media. Edited by L. C. Parks. Boca Raton, FL: CRC Press.

Buck, J. D. (1982). Nonstaining (KOH) method for determination of Gram reactions of marine bacteria. Appl Environ Microbiol 44, 992-993.

Busse, H.-J., Kämpfer, P. \& Denner, E. B. M. (1999). Chemotaxonomic characterisation of Sphingomonas. J Ind Microbiol Biotechnol 23, 242-251.

Ezaki, T., Hashimoto, Y. \& Yabuuchi, E. (1989). Fluorometric deoxyribonucleic acid-deoxyribonucleic acid hybridization in microdilution wells as an alternative to membrane filter hybridization in which radioisotopes are used to determine genetic relatedness among bacterial strains. Int J Syst Bacteriol 39, 224-229.

Felsenstein, J. (1985). Confidence limits on phylogenies: an approach using the bootstrap. Evolution 39, 783-791.

Fitch, W. M. (1971). Toward defining the course of evolution: minimum change for a specific tree topology. Syst Zool 20, 406-416.

Godoy, F., Vancanneyt, M., Martínez, M., Steinbüchel, A., Swings, J. \& Rehm, B. H. A. (2003). Sphingopyxis chilensis sp. nov., a chlorophenol-degrading bacterium that accumulates polyhydroxyalkanoate, and transfer of Sphingomonas alaskensis to Sphingopyxis alaskensis comb. nov. Int J Syst Evol Microbiol 53, 473-477.

Hall, T. A. (1999). BioEdit: a user-friendly biological sequence alignment editor and analysis program for Windows 95/98/NT. Nucleic Acids Symp Ser 41, 95-98.

Hiraishi, A., Ueda, Y., Ishihara, J. \& Mori, T. (1996). Comparative lipoquinone analysis of influent sewage and activated sludge by highperformance liquid chromatography and photodiode array detection. J Gen Appl Microbiol 42, 457-469.

Im, W.-T., Jung, H.-M., Cui, Y.-S., Liu, Q.-M., Zhang, S.-L. \& Lee, S.-T. (2005). Cultivation of the three hundreds of bacterial species from soil of a ginseng field and mining the novel lineage bacteria. In Proceedings of the International Meeting of the Federation of Korean Microbiological Societies, abstract A035, p. 169. Seoul: Federation of Korean Microbiological Societies.

Kämpfer, P., Denner, E. B. M., Meyer, S., Moore, E. R. B. \& Busse, H.-J. (1997). Classification of "Pseudomonas azotocolligans" Anderson 1955, 132, in the genus Sphingomonas as Sphingomonas trueperi sp. nov. Int J Syst Bacteriol 47, 577-583.

Kämpfer, P., Witzenberger, R., Denner, E. B. M., Busse, H.-J. \& Neef, A. (2002). Sphingopyxis witflariensis sp. nov., isolated from activated sludge. Int J Syst Evol Microbiol 52, 2029-2034. 
Kim, M. K., Im, W.-T., Ohta, H., Lee, M. \& Lee, S.-T. (2005) Sphingopyxis granuli sp. nov., a $\beta$-glucosidase-producing bacterium in the family Sphingomonadaceae in $\alpha-4$ subclass of the Proteobacteria. J Microbiol 43, 152-157.

Kimura, M. (1983). The Neutral Theory of Molecular Evolution. Cambridge: Cambridge University Press.

Komagata, K. \& Suzuki, K. (1987). Lipid and cell-wall analysis in bacterial systematics. Methods Microbiol 19, 161-207.

Kouker, G. \& Jaeger, K.-E. (1987). Specific and sensitive plate assay for bacterial lipase. Appl Environ Microbiol 53, 211-213.

Kumar, S., Tamura, K. \& Nei, M. (2004). MEGA3: Integrated software for Molecular Evolutionary Genetics Analysis and sequence alignment. Brief Bioinform 5, 150-163.

Lee, J.-S., Shin, Y. K., Yoon, J.-H., Takeuchi, M., Pyun, Y.-R. \& Park, Y.-H. (2001). Sphingomonas aquatilis sp. nov., Sphingomonas koreensis sp. nov. and Sphingomonas taejonensis sp. nov., yellow-pigmented bacteria isolated from natural mineral water. Int J Syst Evol Microbiol 51, 1491-1498.

Mesbah, M., Premachandran, U. \& Whitman, W. B. (1989). Precise measurement of the $\mathrm{G}+\mathrm{C}$ content of deoxyribonucleic acid by highperformance liquid chromatography. Int J Syst Bacteriol 39, 159-167.

Minnikin, D. E., O’Donnell, A. G., Goodfellow, M., Alderson, G., Athalye, M., Schaal, A. \& Parlett, J. H. (1984). An integrated procedure for the extraction of bacterial isoprenoid quinones and polar lipids. J Microbiol Methods 2, 233-241.

Moore, D. D. \& Dowhan, D. (1995). Preparation and analysis of DNA. In Current Protocols in Molecular Biology, pp. 2-11. Edited by F. M. Ausubel, R. Brent, R. E. Kingston, D. D. Moore, J. G. Seidman, J. A. Smith \& K. Struhl. New York: Wiley.

Pal, R., Bhasin, V. K. \& Lal, R. (2006). Proposal to reclassify [Sphingomonas] xenophaga Stolz et al. 2000 and [Sphingomonas] taejonensis Lee et al. 2001 as Sphingobium xenophagum comb. nov. and Sphingopyxis taejonensis comb. nov., respectively. Int J Syst Evol Microbiol 56, 667-670.

Saitou, N. \& Nei, M. (1987). The neighbor-joining method: a new method for reconstructing phylogenetic trees. Mol Biol Evol 4, 406-425.

Sasser, M. (1990). Identification of bacteria by gas chromatography of cellular fatty acids, MIDI Technical Note 101. Newark, DE: MIDI Inc.

Stackebrandt, E. \& Goebel, B. M. (1994). Taxonomic note: a place for DNA-DNA reassociation and $16 \mathrm{~S}$ rRNA sequence analysis in the present species definition in bacteriology. Int J Syst Bacteriol 44, 846-849.
Takeuchi, M., Kawai, F., Shimada, Y. \& Yokota, A. (1993). Taxonomic study of polyethylene glycol-utilizing bacteria: emended description of the genus Sphingomonas and new descriptions of Sphingomonas macrogoltabidus sp. nov., Sphingomonas sanguis sp. nov., and Sphingomonas terrae sp. nov. Syst Appl Microbiol 16, 227-238.

Takeuchi, M., Sakane, T., Yanagi, M., Yamasato, K., Hamana, K. \& Yokota, A. (1995). Taxonomic study of bacteria isolated from plants: proposal of Sphingomonas rosa sp. nov., Sphingomonas pruni sp. nov., Sphingomonas asaccharolytica sp. nov., and Sphingomonas mali sp. nov. Int J Syst Bacteriol 45, 334-341.

Takeuchi, M., Hamana, K. \& Hiraishi, A. (2001). Proposal of the genus Sphingomonas sensu stricto and three new genera, Sphingobium, Novosphingobium and Sphingopyxis, on the basis of phylogenetic and chemotaxonomic analyses. Int J Syst Evol Microbiol 51, 1405-1417.

Ten, L. N., Im, W.-T., Kim, M.-K., Kang, M.-S. \& Lee, S.-T. (2004). Development of a plate technique for screening of polysaccharidedegrading microorganisms by using a mixture of insoluble chromogenic substrates. J Microbiol Methods 56, 375-382.

Ten, L. N., Baek, S.-H., Im, W.-T., Liu, Q.-V., Aslam, Z. \& Lee, S.-T. (2006). Bacillus panaciterrae sp. nov., isolated from soil of a ginseng field. Int J Syst Evol Microbiol 56, 2861-2866.

Thompson, J. D., Gibson, T. J., Plewniak, F., Jeanmougin, F. \& Higgins, D. G. (1997). The CLUSTAL_X windows interface: flexible strategies for multiple sequence alignment aided by quality analysis tools. Nucleic Acids Res 25, 4876-4882.

Vancanneyt, M., Schut, F., Snauwaert, C., Goris, J., Swings, J. \& Gottschal, J. C. (2001). Sphingomonas alaskensis sp. nov., a dominant bacterium from a marine oligotrophic environment. Int J Syst Evol Microbiol 51, 73-79.

Wayne, L. G., Brenner, D. J., Colwell, R. R., Grimont, P. A. D., Kandler, O., Krichevsky, M. I., Moore, L. H., Moore, W. E. C., Murray, R. G. E. \& other authors (1987). International Committee on Systematic Bacteriology. Report of the ad hoc committee on reconciliation of approaches to bacterial systematics. Int J Syst Bacteriol 37, 463-464.

Yoon, J.-H. \& Oh, T.-K. (2005). Sphingopyxis flavimaris sp. nov., isolated from sea water of the Yellow Sea in Korea. Int J Syst Evol Microbiol 55, 369-373.

Yoon, J.-H., Lee, C.-H., Yeo, S.-H. \& Oh, T.-K. (2005). Sphingopyxis baekryungensis sp. nov., an orange-pigmented bacterium isolated from sea water of the Yellow Sea in Korea. Int J Syst Evol Microbiol 55, $1223-1227$. 